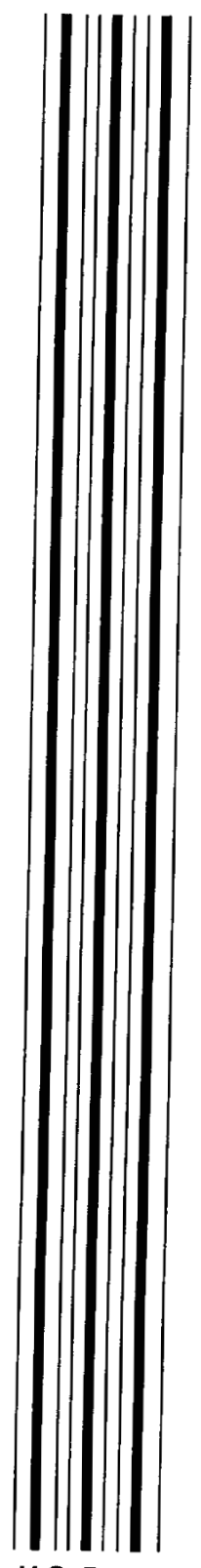

Preprint

UCRL-JC-141286

\title{
Commercial Cokes and Graphites as Anode Materials for Lithium-Ion Cells
}

D. J. Derwin, K. Kinoshita, T. D. Tran, P. Zaleski

This article was submitted to 1998 Materials Research Society Fall Meeting, Boston, MA., November 30-December 4, 1998

U.S. Department of Energy

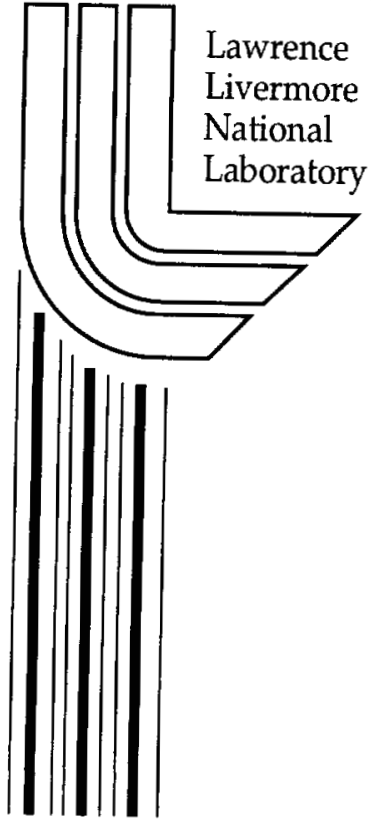

October 26, 2000 


\section{DISCLAIMER}

This document was prepared as an account of work sponsored by an agency of the United States Government. Neither the United States Government nor the University of California nor any of their employees, makes any warranty, express or implied, or assumes any legal liability or responsibility for the accuracy, completeness, or usefulness of any information, apparatus, product, or process disclosed, or represents that its use would not infringe privately owned rights. Reference herein to any specific commercial product, process, or service by trade name, trademark, manufacturer, or otherwise, does not necessarily constitute or imply its endorsement, recommendation, or favoring by the United States Government or the University of California. The views and opinions of authors expressed herein do not necessarily state or reflect those of the United States Government or the University of California, and shall not be used for advertising or product endorsement purposes.

This is a preprint of a paper intended for publication in a journal or proceedings. Since changes may be made before publication, this preprint is made available with the understanding that it will not be cited or reproduced without the permission of the author.

This work was performed under the auspices of the United States Department of Energy by the University of California, Lawrence Livermore National Laboratory under contract No. W-7405-Eng-48.

This report has been reproduced directly from the best available copy.

Available electronically at http://www.doc.gov/bridge

Available for a processing fee to U.S. Department of Energy

And its contractors in paper from

U.S. Department of Energy

Office of Scientific and Technical Information

P.O. Box 62

Oak Ridge, TN 37831-0062

Telephone: (865) 576-8401

Facsimile: (865) 576-5728

E-mail: reports@adonis.osti.gov

Available for the sale to the public from

U.S. Department of Commerce

National Technical Information Service

5285 Port Royal Road

Springfield, VA 22161

Telephone: (800) 553-6847

Facsimile: (703) 605-6900

E-mail: orders@ntis.fedworld.gov

Online ordering: http://www.ntis.gov/ordering.htm

OR

Lawrence Livermore National Laboratory

Technical Information Department's Digital Library

http://www.llnl.gov/tid/Library.html 


\title{
COMMERCIAL COKES AND GRAPHITES AS ANODE MATERIALS \\ FOR LITHIUM - ION CELLS
}

\author{
David J. Derwin *, Kim Kinoshita **, Tri D. Tran +, Peter Zaleski * \\ *Superior Graphite Co., 6540 S. Laramie Ave. Chicago, I1. 60638 \\ * Energy and Environmental Division \\ Lawrence Berkeley National Laboratory, Berkeley, Ca 94720 \\ +Chemistry \& Materials Science Department, \\ Lawrence Livermore National Laboratory, Livermore, Ca. 94550
}

Abstract

Several types of carbonaceous materials from Superior Graphite Co. were investigated for lithium ion intercalation. These commercially available cokes, graphitized cokes and graphites have a wide range of physical and chemical properties. The coke materials were investigated in propylene carbonate based electrolytes and the graphitic materials were studied in ethylene carbonate / dimethyl solutions to prevent exfoliation. The reversible capacities of disordered cokes are below $230 \mathrm{mAh} / \mathrm{g}$ and those for many highly ordered synthetic (artificial) and natural graphites approached $372 \mathrm{mAh} / \mathrm{g}\left(\mathrm{LiC}_{6}\right)$. The irreversible capacity losses vary between 15 to as much as $200 \%$ of reversible capacities for various types of carbon. Heat treated cokes with the average particle size of 10 microns showed marked improvements in reversible capacity for lithium interealation. The electrochemical characteristics are correlated with data obtained from scanning electron microscopy (SEM), high resolution transmission electron microscopy (TEM), $X$ - ray diffraction (XRD) and BET surface area analysis. The electrochemical performance, availability, cost and manufacturability of these commercial carbons will be discussed.

\section{INTRODUCTION}

The carbonaceous materials (both graphite and coke) that will be discussed were supplied by Superior Graphite Co., a leading producer of quality graphite, carbon and related materials for 80 years. Currently producing graphite related products at three different plants, Superior Graphite $C o$. has been able to be a leader in the graphite industry by expanding their operations from graphite mining to graphite processing and finally to the development of engineered graphitic materials. Utilizing Superior Graphite Co.'s unique high temperature furnaces (at the Hopkinsville KY and Russelville, Ark plants) and advanced process technologies with raw material supplies (at the Chicago plant), several 
different types of carbon were examined and processed under.a variety of conditions. Working in conjunction with Lawrence Berkeley National Laboratory and Lawrence Livermore National Laboratory, this study focused on how different carbon based materials, by varying processing steps, could produce low cost materials suitable for application in lithium - ion cells.

\section{EXPERIMENTAL}

The cokes and graphites used in this study have been divided into two classes (graphitized and non graphitized) based on the highest heat treatment temperature to which the carbon was exposed to. This distinction was made because different electrolytes were used to evaluate these two classes of materials to minimize the irreversible capacity loss. Briefly, the non graphitized carbons were tested in propylene carbonate based electrolytes with 0.5 $M$ lithium trifluoromethanesulfonimide. The graphitized carbons were studied in $0.5 \mathrm{M}$ (50/50) ethylene carbonate / dimethyl carbonate.

The powdered materials of known size were used "as received" directly in the electrode fabrication procedure using carbon based binder (1). The larger, more granular carbons were first ground in a mortar and pestle, then sieved to 30 - 40 microns.

Briefly, the electrodes were prepared using a commercial carbon fiber sheet as the support matrix and carbonized phenolic resin binder (10-15\%). A slurny containing the carbon particles, the phenolic resin precursor and furfuryl alcohol was spread on the carbon fiber support and allowed to dry. The composites were pyrolized in $\mathrm{N}_{2}$ at $1050^{\circ} \mathrm{C}$. Cycling experiments for each carbon electrode were carried out in a $15 \mathrm{ml}$ three electrode cylindrical cell. Lithium foils were used as the counter and reference electrodes. Whatman fiberglass filters were used as the separator between the working and counter electrodes. The cells were constructed and tested at $16+1-2^{\circ} \mathrm{C}$ in a dry argon atmosphere glove box ( $<10$ ppm water). The electrode was charged (intercalated) at a constant rate corresponding to 1 mole of lithium per 6 moles of carbon in 24 hours (ca. $\mathrm{C} / 24$ rate) to a cut off voltage of $0.005 \mathrm{~V}\left(\mathrm{Li}^{+} / \mathrm{Li}\right)$ and held at this potential for 4 hours. It was then discharged (deintercalated) at the same rate to insure complete lithium intercalation / deintercalation. Electrochemical studies were performed using a 64 channel Maccor battery tester.

Various equipment, High Resolution Transmission Electron Microscopy (HRTEMD X ray Diffraction (XRD), Scanning Electron Microscope (SEM), BET Surface Area machine and Laser Particle analyzers were used to study and characterize these carbonaceous materials.

\section{RESULTS AND DISCUSSION}

Table 1 lists materials used in this study. This information was obtained from specification sheets or measured in our laboratories.

\section{COKES}

This group of carbons consisted of two grades of calcined petroleum cokes that vary in sulfur content. The two cokes tested, SGC Coke \# 1 (<1\% sulfur) and SGC Coke \#3 (< $3 \%$ sulfur) in general showed different results. The curves for these non graphitic materials have a sloping shape with varying lithium capacity, typical for amorphous carbons. The low sulfur coke (SGC Coke \#1) have $x$ - values near 0.70 with an irreversible capacity around $83 \mathrm{mAh} / \mathrm{g}$. This performance data is comparable to other cokes that have been tested in the laboratory. High sulfur cokes tend to have lower capacities ( $x$ approx. 0.51) and larger irreversible capacities $(110 \mathrm{~mA} / \mathrm{g})$. The capacity of SGC Coke \#1 was stable for more than 20 cycles whereas the capacity of SGC Coke \#3 decreases significantly after 4 cycles. The higher sulfur content of SGC Coke \#3 may affect its performance.

Note : further studies are underway to determine which physical and microstructure properties of calcined petroleum cokes are important for lithium battery usage. These studies include, but are not limited to, different heat treatment temperatures, grinding techniques (before and after heat treatment), tighter particle distributions and surface characteristics.

\section{GRAPHITIZED COKES}

The graphitized petroleum cokes discussed in this section are derived from Superior Graphite Co. patented thermal purification process based in Hopkinsville, KY. This continuous thermal purification process converts calcined petroleum cokes to a purified / partially graphitized product (DESULCO). The temperatures reached during this process, near $2700^{\circ} \mathrm{C}$, eliminate sulfur and other volatile components from the calcined petroleum cokes. DESULCO carbons (SGC 9035) have capacities near $230 \mathrm{mAh} / \mathrm{g}(x=0.60)$. They exhibit graphite like potential curves albeit at lower capacities than those of more crystalline graphites $(\mathrm{LiC})$.

Note : as with the cokes, further studies are underway to determine what physical and microstructure properties of DESULCO are important for lithium battery usage.

\section{GRAPHITE}

Through the same patented thermal purification process used to produce DESULCO, it is possible to take an impure (high ash content) natural graphite and thermally upgrade the carbon value to levels of $99.9+\%$ pure LOI (ash content less than $0.1 \%$ ). Once these impurities have been thermally removed, the resulting graphite can be a candidate for 
lithium battery usage. These thermally purified graphites can be highly crystalline materials that vary in microstructure and morphology, depending on the source. Two of graphites that will be discussed in this section are the thermally purified natural crystalline flake graphite and the thermally purified natural crystalline vein graphite. The thermally purified natural crystalline flake graphite is highly anisotropic in nature. The graphite morphology resembles fiat platelets (flat lamellae) with well defined basal planes. The thermally purified natural crystalline vein graphite is more microcrystalline in nature i.e. smaller crystallites). The graphite morphology is more needle / grain like in shape.

The reversible capacities observed with these materials are about $320-360 \mathrm{mAh} / \mathrm{g}$ which correspond to the $x$ values between $0.85-0.95$ (Table 1). Thermally purified natural flake graphite (SGC 2933 \& SGC BG 39) tend to have a considerably lower capacity than the $\mathrm{LiC}_{6}$ composition. All types of thermally purified natural graphites tested in this study exhibited the graphite like potential curves (i.e., deintercalation / intercalation takes place at potentials below $0.3 \mathrm{~V}$ ). However, there are distinct differences between the profiles of the flake and vein materials. Flake graphites showed plateaus below $0.3 \mathrm{~V}$ that could be identified with the formation of staged phases. For the vein graphites, the curve appears smooth in this region with no apparent plateaus (probably attributed to the microcrystalline nature of the vein graphites).

Note : further studies are underway to determine which characteristics of the thermally purified natural graphites affect lithium battery performance. These future studies on the thermally purified natural graphites do include, but are not limited to, the lowering of surface area (below 3.0 sq.m./g.) and the classifying of the particle size to optimize performance. Also, another source (thermally purified Amorphous graphite) is under investigation.

\section{AVAILABILITY AND COST}

One of the goals of this project was to identify suitable carbon / graphite materials that are inexpensive and commercially available in large quantities. The materials covered in this report are commercially available in large quantities. Superior Graphite CO., an ISO 9001 certified company, has the technology and capability to custom process these materials, and guarantee their sourcing for consistent products. In general, the cost of the thermally purified graphites covered in this report is below $\$ 5.00 / \mathrm{lb}$, with the cokes priced significantly lower.

\section{SUMMARY}

The results show the performance of Superior Graphite CO. carbonaceous materials for lithium ion intercalation. The material shows a wide range of performance characteristics. The electrochemical behavior is related to their physical and structural properties. Many types of carbon appear suitable for application in lithium - ion cells. Work is currently underway to produce and test lower surface area thermally purified natural graphite which have a more controlled particle distribution for lithium battery usage.
TABLE 1.

\section{SUPERIOR GRAPHITE CO.}

\section{GRAPHTIZED AND NON GRAPHITIZED CARBONS}

PROPERTIES AND PERFORMANCE.

\begin{tabular}{|c|c|c|c|c|}
\hline Sample & Type & $\begin{array}{l}\text { Part.size } \\
\text { (microns) }\end{array}$ & $\begin{array}{l}x \text { in } \\
\left(\mathrm{Li}_{\mathbf{x}} \mathrm{C}_{6}\right)\end{array}$ & $\begin{array}{l}\text { Irr. Cap. Loss } \\
\text { (mAhr / g) }\end{array}$ \\
\hline Coke \#1 & $\begin{array}{l}\text { Calcined Pet. Coke } \\
(\text { low sulfur }<1 \%)\end{array}$ & $30-40$ & 0.70 & 83 \\
\hline Coke \#3 & $\begin{array}{l}\text { Calcined Pet. Coke } \\
(\text { sulfur }>2 \%)\end{array}$ & $30-40$ & 0.51 & 110 \\
\hline SGC 9035 & $\begin{array}{l}\text { DESULCO } \\
\text { (grap. Pet. Coke } 2700 \text { deg C) }\end{array}$ & $20-30$ & 0.59 & 129 \\
\hline SGC 2933 & $\begin{array}{l}\text { Purified Flake } \\
\text { (natural graphite) }\end{array}$ & $30-40=$ & 0.86 & 76 \\
\hline SGC BG-39 & $\begin{array}{l}\text { Battery Grade } \\
\text { (purified natural flake graphite) }\end{array}$ & $10-20$ & 0.87 & 98 \\
\hline SGC 4941A & $\begin{array}{l}\text { Purified Vein } \\
\text { (natural graphite) }\end{array}$ & $7-10$ & 0.98 & 130 \\
\hline
\end{tabular}

- Sieved to betwoen indicated range. 


\section{ACKNOWLEDMENT}

The author would like to Tri D. Tran and Kim Kinoshita for their contributions to this paper. This work was supported by the Assistant Secretary for Energy Efficiency and Renewable Energy, Office of Transportation Technologies, Electric \& Hybrid Propulsion (Iawrence Live. Department of Energy under Contract No. W-7405-ENG-48 (Lawrence Livermore National Laboratory) and Contract No. DE-AC0376SF00098
(Lawrence Berkeley Laboratory).

\section{REFERENCES} 1. T. D. Tran, J. H. Feikert, X. Song, and K. Kinoshita, J. Electrochem. Soc. 142, 3297
(1995)

\section{ELECTROCHEMICAL PROPERTIES OF NITROGEN-SUBSTITUTED CARBON AND ORGANOFLUORINE COMPOUNDS}

\section{T. NAKAJIMA, M. KOH, K. DAN}

Division of Polymer Chemistry, Graduate School of Engineering, Kyoto University, Sakyoku, Kyoto, 606-01, Japan

\section{ABSTRACT}

The $\mathrm{C}_{5} \mathrm{~N}$ amples $\left(\mathrm{C}_{14} \mathrm{~N}-\mathrm{C}_{62} \mathrm{~N}\right)$ prepared with a nickel catalyst had the higher crystallinity and less pyridine-type nitrogens existing at the edge of graphene layers than $\mathrm{C}_{z} \mathrm{~N}$ prepared in the absence of catalyst. With increase in the deposition temperature of $\mathrm{C}_{\mathbf{\Omega}} \mathrm{N}$, the cycleability for electrochemical intercalation-deintercalation of lithium ions was improved and the profile of the charge-discharge curve approached that of graphite due to increase in the crystallinity and decrease in the incorporated nitrogens. $\mathrm{C}_{x} \mathrm{~N}$-coated graphites demonstrated gradual increase in the potential at the last stage of lithium ion deintercalation process.

The effect of fluoroester-mixing in $1 \mathrm{M} \mathrm{LiClO}_{4}$-EC/DEC was also investigated at a low temperature. It was found that $\mathrm{CHF}_{2} \mathrm{COOCH}_{3}$ with a low molecular weight and a small number of fluorine atoms was effective as a mixing agent.

\section{INTRODUCTION}

Recently boron- and/or nitrogen-substituted carbons, $\mathrm{BC}_{x} \mathrm{~N}, \mathrm{BC}_{x}$ and $\mathrm{C}_{x} \mathrm{~N}$ were synthesized by chemical vapor deposition (CVD), and their electrochemical behavior as negative electrodes of lithium secondary batteries were investigated [1-4]. These compounds would consitute a new class of candidates for negative electrodes with modified electronic structures, having different chemical interaction with lithium ions. Well crystallized $\mathrm{C}_{2} \mathrm{~N}$ filaments and particles have been synthesized by CVD of acetonitrile or pyridine using a nickel or cobalt catalyst [5]. In this paper, we report the electrochemical behavior of these $\mathrm{C}_{x} \mathrm{~N}$ compounds in $1 \mathrm{M} \mathrm{LiClO}$-EC/DEC. In addition, we have examined the effect of fluoroester-mixing into $1 \mathrm{M} \mathrm{LiClO}$-EC/DEC at a low temperature. The result is also reported.

\section{EXPERIMENT}

The $\mathrm{C}_{m} \mathrm{~N}$ sample were synthesized by thermal decomposition of acetonitrile at 800 $1100^{\circ} \mathrm{C}$ using a nickel catalyst. Flow rate of a mixture of acetonitrile and nitrogen was 55 mlmin ${ }^{-1}$ (partial pressure of acetonitrile: $9.2 \times 10^{3} \mathrm{~Pa}$ ). $\mathrm{C}_{5} \mathrm{~N}$ coating was performed in a similar manner at 9500 using natural graphite powder $(\approx 7 \mu \mathrm{m})$ oxidized by $94 \% \mathrm{HNO}_{3}$. The obtained samples were analyzed by elemental analysis, X-ray diffractometry, SEM, TEM, XPS and Raman spectroscopy.

Electrochemical intercalation and deintercalation of lithium ion into and from $\mathrm{C}_{5} \mathrm{~N}$ sam. les were performed in $1 \mathrm{M} \mathrm{LiClO}-\mathrm{EC} / \mathrm{DEC}$ at a current density of 30 or $60 \mathrm{mAg}^{-1}$ at $25^{\circ} \mathrm{C}$. Counter and reference electrodes were metallic lithium. The effect of fluoroester-mixing was examined at $25^{\circ} \mathrm{C}$ and $0^{\circ} \mathrm{C}$ by adding a reagent grade fluoroester $(2.5 \mathrm{ml}): \mathrm{CHF}_{2} \mathrm{COOCH}_{3} 1$, $\mathrm{CF}_{3} \mathrm{CF}_{2} \mathrm{COOCH}_{2} \mathrm{CH}_{3} 2,\left(\mathrm{CF}_{3}\right)_{2} \mathrm{CHCOOCH}_{3} 3, \mathrm{~F}\left(\mathrm{CF}_{2}\right)_{3} \mathrm{COOCH}_{3} 4, \mathrm{H}\left(\mathrm{CF}_{2}\right)_{4} \mathrm{COOCH}_{2} \mathrm{CH}_{3}$ 5, $\mathrm{F}\left(\mathrm{CF}_{2}\right)_{7} \mathrm{COOCH}_{3} 6$ or $\mathrm{F}\left(\mathrm{CF}_{2}\right)_{7} \mathrm{COOCH}_{2} \mathrm{CH}_{3} 7$, to $1 \mathrm{M} \mathrm{LiClO}_{4}-\mathrm{EC} / \mathrm{DEC}(50 \mathrm{ml})$. Cyclic voltammetry at $0.1 \mathrm{mVsec}^{-1}$ and charge-discharge cycling at $80 \mathrm{mAg}^{-1}$ were conducted for

581

Mat. Res. Soc. Symp. Proc. Vol. $496^{\circ} 1998$ Materials Research Soclety 